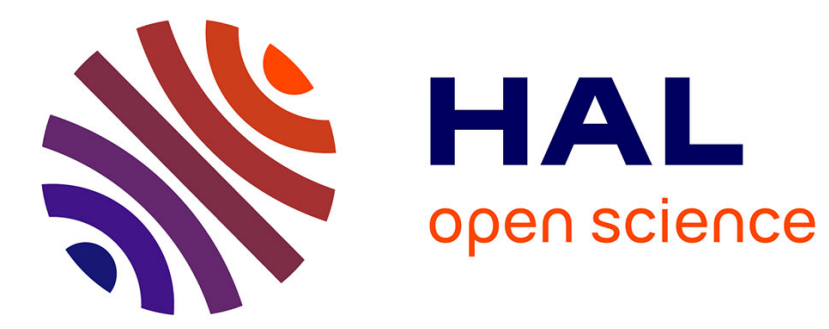

\title{
Pelagic MPAs: The devil is in the details
}

\author{
David Kaplan, Emmanuel Chassot, Arnaud Gruss, Alain Fonteneau
}

\section{To cite this version:}

David Kaplan, Emmanuel Chassot, Arnaud Gruss, Alain Fonteneau. Pelagic MPAs: The devil is in the details. Trends in Ecology and Evolution, 2010, 25 (2), pp.62-63. 10.1016/j.tree.2009.09.003. ird-00470617

\section{HAL Id: ird-00470617 https://hal.ird.fr/ird-00470617}

Submitted on 17 May 2010

HAL is a multi-disciplinary open access archive for the deposit and dissemination of scientific research documents, whether they are published or not. The documents may come from teaching and research institutions in France or abroad, or from public or private research centers.
L'archive ouverte pluridisciplinaire HAL, est destinée au dépôt et à la diffusion de documents scientifiques de niveau recherche, publiés ou non, émanant des établissements d'enseignement et de recherche français ou étrangers, des laboratoires publics ou privés. 


\title{
Pelagic MPAs: The devil is in the details
}

\author{
David M. Kaplan ${ }^{* 1}$ \\ Emmanuel Chassot ${ }^{1}$ \\ Arnaud Gruss ${ }^{1}$ \\ Alain Fonteneau ${ }^{1}$
}

1. Institut de Recherche pour le Développement (IRD), UMR 212 EME, Centre de Recherche Halieutique Méditerranéenne et Tropicale, av. Jean Monnet, B.P. 171, 34203 Sète cedex, France

* Corresponding author - Email: David.Kaplan@ird.fr 
Game et al. (2009) [1] argue "that recent advances across conservation, oceanography and fisheries science provide the evidence, tools and information to... confirm [pelagic] MPAs as defensible and feasible instruments for pelagic conservation". While we agree that pelagic MPAs merit a scientific examination of their potential uses as part of a diversified approach to marine management, reasonable caution must be applied to their implementation and expected benefits. Game et al. (2009) provide an overview of many of the issues, challenges and potential solutions for pelagic MPAs, however we believe that some challenges are likely to be more difficult and costly to resolve than the authors suggest. Here, we consider two such challenges: defining "targeted" MPAs and enforcement. The great mobility of most pelagic species obliges pelagic MPAs to be either exceedingly large or target areas where susceptibility to anthropogenic impacts are higher, such as nursery or spawning zones. The excessive costs of creating very large reserves suggests that the targeted approach is more likely to be implemented. To work, the populations concerned must have high site fidelity as modeling results indicate that even moderate spill-over from reserves significantly reduces MPA benefits [2,3]. While some pelagic species show the levels of site fidelity necessary for "targeted MPAs", this is not always true. For example, though temperate tuna species often aggregate in warmer waters for reproduction [4], many tropical tuna species, such as skipjack Katsuwonus pelamis [5], do not exhibit clear spawning or feeding migrations. This suggests that the effectiveness of targeted MPAs is likely to be species and/or region specific, and could lead to undesirable selection for MPA residency [6].

In addition to the questions linked to the ecological complexity of pelagic resources, effective governance is a major impediment to pelagic MPAs. Game et al. (2009) argue that enforcement of "spatial restrictions might be easier than catch or gear restrictions". However, two recent examples from the Atlantic and Indian Oceans demonstrate that offshore MPA enforcement will be challenging. In the late 1990s, a time-area closure was proposed by the European fishing industries and implemented by purse-seine tuna fisheries in the Gulf of Guinea in an attempt to decrease juvenile catch [7]. This moratorium was largely observed by members of the ICCAT regional fisheries 
management organization (RFMO), but South Korean fishers working under the flag of Ghana largely ignored the closure despite ICCAT membership and the implementation of observer programs. This lack of compliance limited the willingness of European fishermen to maintain the protection plan and made scientific assessment nearly impossible, finally resulting in the near abandonment of the temporal closure in 2005 (reduction in size and from three to one month per year [8]).

Over the last several years, Somali pirates have significantly impacted the Indian Ocean (IO) tuna fleets [9]. In 2007, European and associated flags purse-seiners agreed not to fish in zones of pirate activity, essentially creating a MPA over a zone that normally represents about $38 \%$ of their catch. The wide observance of this "MPA" (Fig 1) demonstrates that a technologically-sophisticated and well-organized fishery can observe a pelagic MPA (given appropriate "incentives"). However, the world's military might has not stopped the pirates for many reasons, some of which are also characteristic of illegal, unreported and unregulated (IUU) fishing: pirates do not use sophisticated technology, are associated with countries lacking enforcement infrastructures and use smaller boats that are harder to track. The Somali example suggests that, at this point in time, pelagic MPAs are unlikely to be more effective at combating IUU fishing than conventional methods.

Despite these challenges, pelagic MPAs are rapidly becoming a reality [10]. We believe these efforts are a positive attempt to diversify management. Nevertheless, there is potential to do considerable harm by moving too quickly with wide-scale implementation. MPAs can generate a false sense of security, particularly when arbitrary target percentages are used [11,12], assessment strategies are not developed and pelagic MPAs have the real potential to be used as cover for increased anthropogenic pressure elsewhere. Based on these dangers, we feel that the utmost attention must be paid towards developing a tempered and science-driven analysis of the uses and abuses of pelagic MPAs.

\section{Acknowledgements}


This work was supported by the AMPED project (www.amped.ird.fr) through a grant from the French National Research Agency (ANR), Systerra Program, grant number ANR-08-STRA-03. We are grateful to J Trolel, E Walker and ORTHONGEL for supplying fishing effort and VMS data, and to ICCAT and IOTC working group members for stimulating discussions on management of pelagic resources.

\section{References}

1. Game, E.T. et al. (2009) Pelagic protected areas: the missing dimension in ocean conservation. Trends Ecol. Evol. 24, 360-369

2. Walters, C.J. et al. (2007) An equilibrium model for predicting the efficacy of marine protected areas in coastal environments. Can. J. Fish. Aquat. Sci. 64, 1009-1018

3. Moffitt, E.A. et al. (in press) Marine reserve networks for species that move within a home range. Ecol. Appl.

4. Rooker, J.R. et al. (2008) Natal Homing and Connectivity in Atlantic Bluefin Tuna Populations. Science 322, 742-744

5. Stéquert, B. and Ramcharrun, R. (1996) Reproduction of skipjack tuna (Katsuwonus pelamis) from the Western Indian Ocean. Aquat. Living Resour. 9, 235-247

6. Dawson, M.N. et al. (2006) Connectivity in marine protected areas. Science 313, 43-44

7. ICCAT (1999) Recommendation - Closed area/season to FADs. Available: http://www.iccat.int/Documents\%5CRecs\%5Ccompendiopdf-e\%5C1999-01-e.pdf. Accessed 13 July 2009.

8. ICCAT (2004) Recommendation by ICCAT on a multi-year conservation and management program for bigeye tuna. Available: http://www.iccat.int/Documents\%5CRecs\%5Ccompendiopdf-e \%5C2004-01-e.pdf. Accessed 13 July 2009. 
9. UNOSAT (2009) Analysis of Somali pirate acrivity in 2009. Available: http://unosat.web.cern.ch/unosat/freeproducts/somalia/Piracy/2009/UNOSAT_Somalia_Pirates_An alysis_Q1_2009_23Apri109_v1.pdf. Accessed 13 July 2009.

10. Pala, C. (2009) Protecting the Last Great Tuna Stocks. Science 324, 1133

11. Roberts, C.M. et al. (2006) Roadmap to Recovery: A global network of marine reserves. York, UK: Greenpeace. 56 p. Available: http://www.greenpeace.at/uploads/media/Roadmap_to_recoveryMarine_reserves_01.pdf.

12. Sumaila, U.R. et al. (2007) Potential costs and benefits of marine reserves in the high seas. Mar. Ecol. Prog. Ser. 345, 305-310 


\section{Figure Captions}

Fig 1 VMS readings of French purse-seine boat positions from the third quarter of 2008. Positions, which include both transit and fishing locations, are indicated by black dots. The outline of Somalia is in blue with its economic exclusion zone (EEZ) indicated by a dashed blue line. The green curve shows the agreed limit of the no-fishing zone at the time (300 n.m. from Somali coast; it has since been extended). Red numbers show the expansion of pirate attacks on French purse-seiners since 2008: (1) 14-May-2008, (2) 11-Sep-2008, (3) 13-Sep-2008, (4) 20-Feb2009, (5) 23-Feb-2009, (6) 20-May-2009.

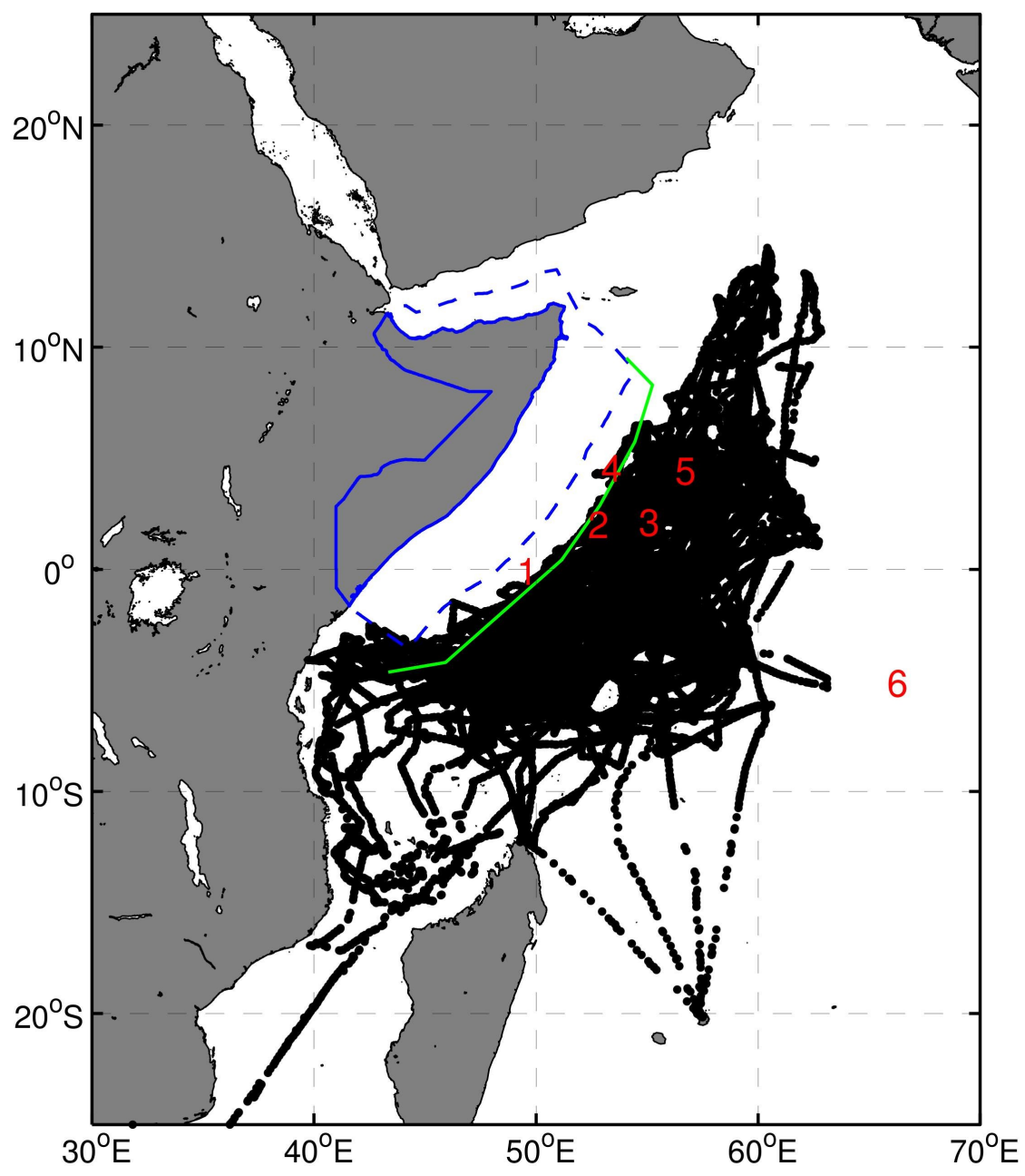

